\title{
Selected Parameters of Nutritional and Pro-Health Value in the Common Carp (Cyprinus carpio L.) Muscle Tissue
}

\author{
J. Kłobukowski $\mathbb{D}^{1},{ }^{1}$ K. Skibniewska, ${ }^{2}$ K. Janowicz $\mathbb{D}^{1},{ }^{1}$ F. Kłobukowski, ${ }^{3}$ \\ E. Siemianowska, ${ }^{2}$ E. Terech-Majewska, ${ }^{4}$ and J. Szarek ${ }^{5}$ \\ ${ }^{1}$ Department of Human Nutrition, University of Warmia and Mazury in Olsztyn, Olsztyn, Poland \\ ${ }^{2}$ Department of Foundations of Safety, University of Warmia and Mazury in Olsztyn, Olsztyn, Poland \\ ${ }^{3}$ Department of Food Commodity Science, Medical University of Gdańsk, Gdańsk, Poland \\ ${ }^{4}$ Department of Epizootiology, University of Warmia and Mazury in Olsztyn, Olsztyn, Poland \\ ${ }^{5}$ Department of Pathophysiology, Forensic Veterinary Medicine and Administration, University of Warmia and Mazury in Olsztyn, \\ Olsztyn, Poland
}

Correspondence should be addressed to K. Janowicz; katarzyna.janowicz@uwm.edu.pl

Received 12 December 2017; Revised 10 February 2018; Accepted 27 February 2018; Published 26 April 2018

Academic Editor: Domenico Montesano

Copyright (C) 2018 J. Kłobukowski et al. This is an open access article distributed under the Creative Commons Attribution License, which permits unrestricted use, distribution, and reproduction in any medium, provided the original work is properly cited.

\begin{abstract}
This study analysed the effect of the type of production on the nutritional and health value of common carp muscle tissue, especially lipid-related indexes. The muscle tissue of common carps originating from three types of fish farms with different technological levels (i.e., intensive, low-intensive, and semiextensive) was studied. The type of production technology, especially the intensive breeding technique, has been shown to have a significant effect on dry weight, total protein, and total fat content in the common carp muscle tissue under study. The muscles of fish originating from these farms were characterised by the highest values of the mentioned indicators, which amounted to $24.6 \%, 18.74 \%$, and $1.58 \%$, respectively, for dry matter, protein content, and total fat content. The type of feed used in intensive, low-intensive, and semiextensive common carp breeding has been proven to have a highly significant effect on the fatty acid profile. As regards unsaturated fatty acids, monounsaturated fatty acids were dominant in all cases. The muscle tissue of fish cultured in farms with a semiextensive technological level was characterised by the highest content of unsaturated fatty acids. Moreover, the ratio of polyunsaturated fatty acids to saturated fatty acids was, in this case, the most favourable. Dietary indices of atherogenicity (AI) and thrombogenicity (TI) were studied as well. In all analysed cases, the values of these indices were very favourable and several times lower than for other animal fats.
\end{abstract}

\section{Introduction}

Consumption of fish in Central and Eastern Europe is still insufficient, which is a consequence of consumers' unsatisfactory knowledge and prices. Greater demand for this type of food is observed among people with university education and in circles where eating fish is a family tradition [1]. However, it is beyond doubt that increasing attention is being paid to food quality, both in Poland and elsewhere. The quality of fish muscle tissue, in terms of both the qualitative and the quantitative characteristics, including its nutritional value and chemical composition of muscles, can be modified by changing breeding conditions and, more specifically, feeding technologies.
Considerations of the pro-health effect of food must take into account the important role of animal origin fat, including polyunsaturated fatty acids and cholesterol in human nutrition. Fish, which is a food unmodified over the centuries and which can be regarded as one of humans' prime foods, is a valuable source of those nutrients $[2,3]$. The spectrum of health-promoting effects of n-3 PUFAs on the cardiovascular system is very broad. Numerous studies have demonstrated that the consumption of a large number of foods providing a source of these acids, inter alia the application of a Mediterranean diet that is rich in fish, contributes to a reduction in the risk of the incidence of coronary heart disease and cardiac insufficiency. Moreover, the effectiveness of PUFAs in the course of coronary heart 
disease and cardiac insufficiency and in the prevention of atrial fibrillation attacks was also confirmed. Experts agree on the nutritional recommendations concerning the consumption of PUFAs. In 2004, the International Society for the Study of Fatty Acids and Lipids recommended that $500 \mathrm{mg}$ EPA and DHA should be consumed on a daily basis to prevent the occurrence of ischaemic heart disease. Similar recommendations were issued by the European Food Safety Authority (daily intake of $250 \mathrm{mg}$ EPA and DHA for adults (EFSA 2010)) as well as by German, Austrian, and Swiss nutritional associations (DGE/ÖGE/SGE 2008) [4]. Polyunsaturated fatty acids play an extremely important role in the proper functioning of the human body. They provide a substrate for the synthesis of eicosanoids, that is, tissue hormones that regulate the functions of other hormones and neurotransmitters [5]. Fish fat abounds in C22:6 n-3 docosahexaenoic acid (DHA), C20:5 n-3 eicosapentaenoic acid (EPA), and C18:3 n-3 linolenic acid, whose beneficial effect on human health has been corroborated by research [6]. Much has been said about the benefits resulting from the consumption of polyunsaturated fatty acids in the context of the primary and secondary prevention of ischaemic heart disease; however, the most interesting studies are those probing the relationship between the diet and the risk of the occurrence of depression. Sánchez-Villegas et al. [7] studied the relationship between the consumption of lipids and the incidence of depression in the Mediterranean population. An increased risk of depression occurrence resulting from the increased consumption of trans-isomers of unsaturated fatty acids was demonstrated. At the same time, a weak negative correlation was observed between the consumption of MUFAs and PUFAs and the occurrence of such mental disorders. A sufficient supply of good quality fat has a protective effect on the human circulatory and nervous system. Fish muscle tissue also supplies large amounts of vitamins $B, A$, and $D$, and its proteins are easily absorbable and have a beneficial amino acid profile $[8,9]$.

Common carp, like the rainbow trout, is popular in many regions of Europe and it is one of the freshwater fish with a high nutritional value. Numerous studies of breeding, particularly the feeding of common carp, have shown the significant effect of the type of feed on the slaughter yield and quality of common carp muscle tissue, especially the content of protein, total fat, mono- and polyunsaturated fatty acids, and cholesterol $[10,11]$. Therefore, this study attempted to determine the effect of the type of production on the nutritional and health value of common carp muscle tissue, especially the lipid-related indexes. The particular role of the common carp in human nutrition was confirmed by an experiment conducted by Adamkova et al. (2011) [12], who studied the effects of the incorporation of common carps into the diet as an element of secondary prevention in people suffering from ischaemic heart disease. Two representative groups of people (a test group and the control group) were subjected to testing. In the diet of the first one, $200 \mathrm{~g}$ of a fillet of common carp fed with a mixture with increased n-3 PUFA content ( $439 \pm 146 \mathrm{mg} / 100 \mathrm{~g}$ of the fillet) was incorporated. The total energy consumption in both groups was the same. The results of laboratory tests carried out after four weeks of the experiment clearly indicated the positive effect of the consumption of common carp in the event of CVDs. Plasma lipid levels were significantly improved in the group of patients who had fish incorporated into their diet compared to the control group. A reduction in the total cholesterol level by $27 \%$ was demonstrated, with a decrease by $2 \%$ in the control group $(p<0.001)$. LDL cholesterol level decreased by $26 \%$ as compared to $4 \%(p<0.001)$; the TG value in the plasma decreased by $26 \%$ as compared to $3 \%(p<0.001)$. An increase in HDL cholesterol level by $30 \%$ in relation to $10 \%$ was observed $(p<0.001)$. Based on a POLKARD-SPOK study, Filipiak and Opolski [13] indicate the occurrence of disturbances in lipid metabolism in $78 \%$ of the population of patients at high risk of death due to CVDs. The data suggests that it is beneficial to enrich the diet with polyunsaturated fatty acids to improve the values of blood serum lipidogram through an increase in the consumption of common carp, particularly in Central European countries.

\section{Material and Methods}

Material from five fish farms in different locations in Poland was used in the study; the production technology applied in them was intensive (I) in 2 farms, low-intensive (NI) in 1 farm, and semiextensive (SE) in 2 farms. In order to avoid the effect of climate on the growth of common carps, which are poikilotherms, samples were taken from ponds situated in various parts of the country. Most farms were characterised by single-season production. Only one of the farms, with a semiextensive technological level, carried out multiseason production. Of the mentioned types of farms, three types of ponds were noted: commercial and fattening fish bins (I), only commercial (NI), and commercial I recreational and angling (SE). The stocking density in the farm applying the intensive production technology was 1,600 fish/ha, in the ponds with the low-intensive technological level was 1,315 fish/ha, and for the semiextensive production was $600 \mathrm{fish} / \mathrm{ha}$. Particular farms were distinguished by production at a level of $1,002.5 \mathrm{~kg} / \mathrm{ha}, 993 \mathrm{~kg} / \mathrm{ha}$, and $659 \mathrm{~kg} / \mathrm{ha}$, respectively, for the intensive, low-intensive, and semiextensive technological levels. On average, the weight of common carps harvested in the farm with intensive production technology was $1,159.5 \mathrm{~g}$ per fish; common carps harvested from the ponds with the low-intensive production technology had an average weight of $1,523 \mathrm{~g}$ per fish, whereas those from ponds characterised by semiextensive production technology had an average weight of $1,424 \mathrm{~g}$ per fish. The following types of feed were used in different farms:

(i) Cereal mixture-wheat, barley, and rye in the ratio of $3: 1: 1$ or only fishing bait in semiextensive farms.

(ii) Cereal mixture (wheat, barley, and rye in the ratio of $2: 1: 1$ ) or a cereal mixture (maize + wheat and barley in the ratio of 1:3) in low-intensive production technology.

(iii) Granulate Aller-Aqua, which comprises dried distiller grain, sunflower protein concentrate, soybean protein concentrate, fish meal, poultry meal, blood meal, feather meal, rapeseed oil, wheat, triticale, rape, soybean, vitamins, minerals, and amino acids, in intensive production technology. 
Altogether, 75 fish were taken for the study, 15 consumer common carps of the $S$ grade $(0.8-1 \mathrm{~kg})$ and $D$ grade $(1-2 \mathrm{~kg})$. The fish were then killed, boned, and stored at $-18^{\circ} \mathrm{C}$.

In order to conduct a chemical analysis, a $5 \mathrm{~cm}$ wide boneless and skinless section was taken from a frozen fillet from the ventral to the dorsal side. The next stage involved grinding and homogenisation of a sample in a homogeniser (Type PRO350 BIOEKO, time: 40 minutes, speed: 11,000 RPM).

The dry weight was determined by drying samples to a constant mass, in accordance with the guidelines of AOAC [14]. Total ash was determined by drying, carbonising, and incineration [14]. Total protein content (nitrogen $\times 6.25$ ) was determined by the Kjeldahl method [15].

Fat was extracted in accordance with the procedure proposed by Folch et al. [16]. Two-gram homogenised samples of muscle tissue were homogenised with $20 \mathrm{ml}$ of methanol for 1 minute and with $40 \mathrm{ml}$ of chloroform, also for 1 minute. The homogenate was filtered through a degreased filter. The remainder was washed with $60 \mathrm{ml}$ of mixture of methanol and chloroform at a ratio of $2: 1$. The filtrate was then washed with $40 \mathrm{ml}$ of chloroform and $20 \mathrm{ml}$ of methanol and combined with $0.88 \%$ of sodium chloride at $25 \%$ of the filtrate volume. The mixture was shaken and left overnight for the layers to separate. The upper layer was collected with a vacuum pump and rejected. The lower layer was a lipid extract. A mixture of water and methanol in a ratio of 1:1 was added to it, in two replicates, in an amount of $1 / 4$ of the amount of filtrate, and its top layer was each time discarded. The lipid extract was filtered through calcined sodium sulphate (VI) on a degreased filter and the solvent was then distilled off. The remainder was weighed in accordance with AOAC 2002 guidelines [17].

Methyl esters of fatty acids were prepared by the modified method developed by Peisker [18]. A $0.5 \mathrm{~g}$ sample of fat was put into an ampoule, $2 \mathrm{~cm}^{3}$ of methylating mixture (methanol:chloroform: concentrated sulphuric acid, at a ratio of $100: 100: 1(\mathrm{v} / \mathrm{v} / \mathrm{v}))$ was added, and the ampoule was sealed. The ampoules were heated in a water bath for two hours at $100^{\circ} \mathrm{C}$. The fatty acids were analysed by gas chromatography on a $6890 \mathrm{~N}$ Agilent Technologies chromatograph under the following conditions: capillary column with internal diameter of $0.32 \mathrm{~mm}$, length $30 \mathrm{~m}$ (Supelcowax 10 liquid phase, film thickness of $0.25 \mu \mathrm{m}$ ), injector (split $50: 1$ ) (flow rate of $10 \mathrm{ml} / \mathrm{min}$ ), injector temperature of $225^{\circ} \mathrm{C}$, detector temperature of $250^{\circ} \mathrm{C}$, and column temperature of $180^{\circ} \mathrm{C}$. Fatty acids were identified through a comparison of retention times of the standards (a mixture of 37 acids) and peaks in the test sample.

The gross calorific value $\left(W_{B-} \mathrm{kcal} / 100 \mathrm{~g}\right)$ of breeding common carp muscle tissue was calculated using physical energy equivalents from the following formula: $W_{B}=5.65 *$ $B+9.45 * T+4.15 * W[\mathrm{kcal} / \mathrm{g}]$, where $B$ is the protein content in a sample, $\mathrm{g} / 100 \mathrm{~g} ; T$ is the fat content in a sample, $\mathrm{g} / 100 \mathrm{~g}$; $W$ is the carbohydrates content in a sample, g/100 g; 5.65, 9.45, and 4.15 are physical energy equivalents for proteins, fats, and carbohydrates, respectively, $\mathrm{kcal} / \mathrm{g}$.

The net calorific value $\left(W_{n-} \mathrm{kcal} / 100 \mathrm{~g}\right)$ of the carcasses was calculated using Atwater net equivalents, from the following formula: $W_{N}=4 * B+9 * T+4 * W[\mathrm{kcal} / \mathrm{g}$ ] [19], where $B$ is the protein content in a sample, $g / 100 \mathrm{~g}$; $T$ is the fat content in a sample, g/100 g; $W$ is the carbohydrates content in a sample, $\mathrm{g} / 100 \mathrm{~g} ; 4,9$, and 4 are Atwater net equivalents for proteins, fats, and carbohydrates, respectively, $\mathrm{kcal} / \mathrm{g}$. When the calorific values $W_{B}$ and $W_{N}$ were expressed in $\mathrm{kJ} / 100 \mathrm{~g}$, a conversion factor of $1 \mathrm{kcal}=4.19 \mathrm{~kJ}$ was applied. Since common carp muscle tissue contains only trace amounts of carbohydrates; this energy component was left out of the calculations [19].

The dietary atherogenic index (AI) and thrombogenic index (TI) were estimated with the formulae developed by Ulbricht and Southgate [20]. The atherogenic index was calculated from the formula $\mathrm{AI}=\mathrm{C} 12: 0+4 \mathrm{C} 14: 0$

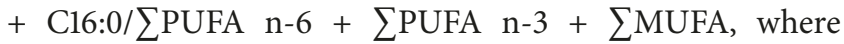
C12:0, C14:0, and C16:0 are the content of saturated acids: lauric, myristic, and palmitic (\%); $\sum$ PUFA n-6 are the total polyunsaturated fatty acids n-6 (\%); $\sum$ PUFA n-3 are the total polyunsaturated fatty acids n-3 (\%); $\sum$ MUFA are the total monounsaturated fatty acids (\%). The thrombogenic index (TI) was calculated from the formula TI $=$ C14:0 + C16:0 + C18:0/(0.5* C18:1) + 0,5 (MUFA-C18:1) + $(0,5 *$ PUFA $n-$ 6) $+3 *$ PUFA n-3 + (PUFA n-3/PUFA n-6), where: C14:0, C16:0, and C18:0 are the content of saturated acids: myristic, palmitic, and stearic (\%); MUFA is monounsaturated fatty acid; PUFA n-6 are polyunsaturated fatty acids n-6 (\%); PUFA $n-3$ are polyunsaturated fatty acids $n-3(\%)$.

The statistical analysis was performed using Statistica 12 software, with the $t$-test for samples independent from groups at $p \leq 0.05$.

\section{Results}

An analysis of the composition of common carp muscle tissue from fish farms of three types has shown a distinct effect of the method of feeding on the nutritional and energy value of the meat. Common carp muscle tissue from a farm which applied the intensive breeding technology had the highest calorific value (gross: $182 \mathrm{kcal}$; net: $102 \mathrm{kcal}$ ) followed by the material from farms where semiextensive production technology was applied (116 and $91 \mathrm{kcal}$, resp.). The lowest calorific value was recorded for the muscle tissue of common carp bred by the low-intensive technology; the gross calorific value of the product was $109 \mathrm{kcal}$ and net calorific value was $88 \mathrm{kcal}$ (Table 1). The net calorific value is an especially important parameter for living organisms; it is the amount of energy actually used by an organism for life processes. The muscles of fish fed by the intensive method also contained the highest percentage of dry matter (24.6\%), protein (18.74\%), and fat $(1.58 \%)$ in the carcass, which obviously has its effect on the calorific value. Moreover, the content of dry matter is closely connected with the amount of fat in muscle tissue, as it is a component whose form does not change significantly during drying. Muscle tissue of fish from low-intensive breeding contained the lowest level of fat of all the samples: $0.56 \%$. The dry matter content was $22.31 \%$ and the total protein content was $18.32 \%$ (Table 1). Despite the similarity of the feed used in low-intensive and semiextensive farms (cereal mixtures), the higher protein content in fish muscle tissue from the 
TABLE 1: Calorific value and basic chemical composition in muscle tissue of common carp samples under study.

\begin{tabular}{|c|c|c|c|c|}
\hline \multirow{2}{*}{ Item } & & \multicolumn{3}{|c|}{ Production technology } \\
\hline & & Intensive $(n=30)$ & Low-intensive $(n=15)$ & Semiextensive $(n=30)$ \\
\hline Gross calorific value (kcal/100 g) & $\bar{x}$ & 182 & 109 & 116 \\
\hline Gross calorific value (kJ/100 g) & $\bar{x}$ & 764 & 458 & 487 \\
\hline Net calorific value (kcal/100 g) & $\bar{x}$ & 102 & 88 & 91 \\
\hline Net calorific value (kJ/100 g) & $\bar{x}$ & 428 & 370 & 382 \\
\hline \multirow{2}{*}{ Dry matter (\%) } & $\bar{x}$ & $24.6^{\mathrm{a}}$ & $22.31^{\mathrm{b}}$ & $21.98^{b}$ \\
\hline & SD & 0.34 & 0.82 & 0.81 \\
\hline \multirow{2}{*}{ Total protein $(\%)$} & $\bar{x}$ & $18.74^{\mathrm{a}}$ & $18.32^{\mathrm{a}}$ & $17.94^{\mathrm{a}}$ \\
\hline & SD & 0.63 & 0.43 & 0.33 \\
\hline \multirow{2}{*}{ Total fat (\%) } & $x$ & $1.58^{\mathrm{a}}$ & $0.56^{\mathrm{b}}$ & $1.49^{\mathrm{a}}$ \\
\hline & SD & 0.96 & 0.11 & 0.68 \\
\hline \multirow{2}{*}{ Total ash (\%) } & $\bar{x}$ & $1.01^{\mathrm{a}}$ & $1.11^{\mathrm{a}}$ & $1.02^{\mathrm{a}}$ \\
\hline & SD & 0.03 & 0.24 & 0.07 \\
\hline
\end{tabular}

${ }^{\mathrm{a}, \mathrm{a}}$ The same letters in a row denote the absence of significant statistical differences between mean values at $p \leq 0.05 .{ }^{\mathrm{a}, \mathrm{b}}$ Different letters in a row denote the presence of significant statistical differences between mean values at $p \leq 0.05$.

first type of breeding could be an effect of an addition of maize in the feed. This cereal contains similar levels of protein to other species, but it was an additional component of the feed, thereby increasing its consumption by fish. Regardless of the feed or production technology, monounsaturated fatty acids dominated in common carp muscle tissue (Table 2). A statistical analysis of the content of monounsaturated fatty acids has revealed significant differences in the content of MUFA in muscle tissue of common carp from farms where intensive and low-intensive production technologies were applied (Table 2). Oleic acid (C18:1 n-9) dominated among monounsaturated fatty acids in all cases. Only for C15:0 pentadecanoic acid were the differences not statistically significant. Statistically significant differences have been demonstrated between all of the fatty acids in the profiles of monounsaturated fatty acids in muscle tissue of fish which were given natural feed and bred by low-intensive technology. A comparison of intensive and semiextensive farms did not reveal any statistically significant differences for C20:0 eicosanoic acid. There were some statistically significant differences between the other fatty acids, which were significantly affected by differentiating fodder and highprotein mixtures, enriched with animal fats and natural plant feed (Table 2).

Intensive fish production enables one to provide fish with the right amount of feed as well as to achieve the desired dietary value of the finished product. The study found that common carp muscle tissue bred by this model is significantly richer in essential polyunsaturated fatty acids (PUFAs) (Table 2). An analysis of the fatty acid profile of muscle tissue of the common carp under study shows a large content of PUFA in muscles of all the fish (Table 2). C18:2 n-6, C20:5 n3, C20:4 n-6, and C22:6 n-3 acids dominated among PUFAs in all samples. A comparison of fish from intensive and low-intensive breeding farms showed statistically significant differences in the content of fatty acids in most cases. No differences were observed in the content of the following fatty acids: C18:4 n-3, C20:1 n-9, C20:1 n-7, C20:3 n-3, C20:4 $\mathrm{n}-3$, and C20:5 n-6. Not many significant differences were found between the fatty acid contents in common carp muscle tissue from the two extreme types of fish farms: intensive and semiextensive. Only for C18:2 n-6 or C20:1 n-9 acids were no statistically significant differences found. Only two cases with no statistically significant difference were identified in an analysis of common carp muscle tissue by the low-intensive and semiextensive method. Those were the content levels of fatty acids C20:2 n-9 and C22:6 n-3 (Table 2). It can be concluded from the results of the statistical analysis of the fatty acid profile of fish muscle tissue from three types of fish farms that the type of feed has a great effect on its composition. The contents of various profile components vary from one fish type to another. There are some other cases with no differences between them, but only on the farms where intensive and low-intensive production technology was applied. This arises from the similarity of feed used in these fish ponds and the small number of results with no statistically significant differences between farms: I-SE, LE-SE, which clearly shows the differences in the nutritional value of the feed and translates into the material composition. Regardless of the type of common carp production technology, the fish fat contained saturated and unsaturated fatty acids at a beneficial ratio (Figure 1). The ratio was 0.84 in common carp caught on intensive farms, 0.74 in the low-intensive ones, and 0.87 in semiextensive ones. An examination of the fatty acid profile in common carp muscles has shown that they are not only a source of PUFA n-3 and PUFA n-6; the values of AI and TI are considerably lower than for other animal fats (Figure 2). For example, the atherogenic index for cow milk is ca. 3-4. The values for fish muscle tissue are $0.43,0.54$, and 0.35 for intensive, lowintensive, and semiextensive technology, respectively. For the samples of muscles under study, the values were 0.46 , 0.65 , and 0.84 for intensive, low-intensive, and semiextensive breeding, respectively. 
TABLE 2: Fatty acid profile in muscle tissue of common carp under study (\%).

\begin{tabular}{|c|c|c|c|}
\hline \multirow[b]{2}{*}{ Fatty acids } & \multicolumn{3}{|c|}{ Production technology } \\
\hline & Intensive $(n=30)$ & Low-intensive $(n=15)$ & Semiextensive $(n=30)$ \\
\hline \multicolumn{4}{|l|}{ Saturated fatty acids } \\
\hline $\mathrm{C} 14: 0$ & $1.59^{\mathrm{a}}$ & $1.44^{\mathrm{b}}$ & $0.84^{\mathrm{c}}$ \\
\hline $\mathrm{C} 15: 0$ & $0.3^{\mathrm{a}}$ & $0.22^{\mathrm{a}}$ & $0.1^{\mathrm{b}}$ \\
\hline $\mathrm{C} 16: 0$ & $19.02^{\mathrm{a}}$ & $21.65^{\mathrm{b}}$ & $18.3^{\mathrm{c}}$ \\
\hline $\mathrm{C} 17: 0$ & $0.28^{\mathrm{a}}$ & $0.19^{\mathrm{b}}$ & $0.13^{\mathrm{c}}$ \\
\hline $\mathrm{C} 18: 0$ & $5.05^{\mathrm{a}}$ & $5.58^{\mathrm{b}}$ & $6.40^{c}$ \\
\hline C20:0 & $0.11^{\mathrm{a}}$ & $0.08^{\mathrm{b}}$ & $0.11^{\mathrm{a}}$ \\
\hline $\mathrm{C} 22: 0$ & $0.19^{\mathrm{a}}$ & $0.03^{\mathrm{b}}$ & $0^{\mathrm{c}}$ \\
\hline Total ratio UFA & 26,54 & 29,19 & 25,88 \\
\hline \multicolumn{4}{|c|}{ Monounsaturated fatty acids } \\
\hline $\mathrm{C} 14: 1$ & $0.09^{\mathrm{a}}$ & $0.08^{\mathrm{b}}$ & $0.04^{\mathrm{c}}$ \\
\hline $\mathrm{C} 16: 1 \mathrm{n}-7$ & $8.65^{\mathrm{a}}$ & $10.29^{\mathrm{b}}$ & $8.17^{\mathrm{c}}$ \\
\hline $\mathrm{C} 17: 1$ & $0.37^{\mathrm{a}}$ & $0.25^{\mathrm{b}}$ & $0.15^{\mathrm{c}}$ \\
\hline C18:1 n-9 & $33.87^{\mathrm{a}}$ & $39.99^{\mathrm{b}}$ & $45.61^{\mathrm{c}}$ \\
\hline C18:1 n-7 & $3.55^{\mathrm{a}}$ & $2.96^{\mathrm{b}}$ & $2.52^{\mathrm{c}}$ \\
\hline C20:1 n-11 & $0.38^{\mathrm{a}}$ & $0.32^{\mathrm{a}}$ & $0.16^{\mathrm{b}}$ \\
\hline C20:1 n-9 & $2.28^{\mathrm{a}}$ & $2.1^{\mathrm{a}}$ & $2.24^{\mathrm{ab}}$ \\
\hline C20:1 n-7 & $0.10^{\mathrm{a}}$ & $0.09^{\mathrm{a}}$ & $0.05^{\mathrm{b}}$ \\
\hline C22:1 n-11 & $0.37^{\mathrm{a}}$ & $0.09^{\mathrm{b}}$ & $0.06^{\mathrm{c}}$ \\
\hline $\mathrm{C} 22: 1 \mathrm{n}-9$ & $0.14^{\mathrm{a}}$ & $0.07^{\mathrm{b}}$ & $0.05^{\mathrm{c}}$ \\
\hline Total ratio MUFA & 49,8 & 56,24 & 59,05 \\
\hline \multicolumn{4}{|c|}{ Polyunsaturated fatty acids } \\
\hline C18:3 n-3 & $3.03^{\mathrm{a}}$ & $2.06^{\mathrm{b}}$ & $0.71^{\mathrm{c}}$ \\
\hline $\mathrm{C} 18: 4 \mathrm{n}-3$ & $0.73^{\mathrm{a}}$ & $0.52^{\mathrm{a}}$ & $0.14^{\mathrm{b}}$ \\
\hline$C 20: 3 n-3$ & $0.15^{\mathrm{a}}$ & $0.14^{\mathrm{a}}$ & $0.07^{\mathrm{b}}$ \\
\hline $\mathrm{C} 20: 4 \mathrm{n}-3$ & $0.36^{\mathrm{a}}$ & $0.28^{\mathrm{a}}$ & $0.14^{\mathrm{b}}$ \\
\hline$C 20: 5 n-3$ & $2.59^{\mathrm{a}}$ & $1.34^{\mathrm{b}}$ & $0.73^{\mathrm{c}}$ \\
\hline $\mathrm{C} 22: 5 \mathrm{n}-3$ & $0.85^{\mathrm{a}}$ & $0.38^{\mathrm{b}}$ & $0.27^{\mathrm{c}}$ \\
\hline $\mathrm{C} 22: 6 \mathrm{n}-3$ & $2.20^{\mathrm{a}}$ & $0.96^{\mathrm{b}}$ & $0.84^{\mathrm{b}}$ \\
\hline Total ratio n-3 & 9,91 & 5,68 & 2,9 \\
\hline C18:2 n-6 & $10.59^{\mathrm{a}}$ & $7.13^{\mathrm{b}}$ & $9.92^{\mathrm{a}}$ \\
\hline $\mathrm{C} 18: 3 n-6$ & $0.32^{\mathrm{a}}$ & $0.24^{\mathrm{b}}$ & $0.37^{\mathrm{c}}$ \\
\hline$C 20: 3 n-6$ & $0.44^{\mathrm{a}}$ & $0.25^{\mathrm{b}}$ & $0.33^{\mathrm{c}}$ \\
\hline C20:4 n-6 & $1.55^{\mathrm{a}}$ & $0.85^{\mathrm{b}}$ & $1.06^{\mathrm{c}}$ \\
\hline $\mathrm{C} 22: 5 \mathrm{n}-6$ & $0.14^{\mathrm{a}}$ & $0.14^{\mathrm{a}}$ & $0.22^{\mathrm{b}}$ \\
\hline Total ratio n-6 & 13,04 & 8,61 & 11,09 \\
\hline Ratio n-3/n-6 & 0,74 & 0,66 & 0,26 \\
\hline C20:2 n-9 & $0.41^{\mathrm{a}}$ & $0.29^{\mathrm{b}}$ & $0.28^{\mathrm{b}}$ \\
\hline Total ratio PUFA & 23,36 & 14,58 & 15,08 \\
\hline
\end{tabular}

\section{Discussion}

The muscle tissue of common carp fed exclusively with cereal mixtures or fishing bait (i.e., food of a simple composition, without being enriched with animal protein or fat, therefore having a lower nutritional value) contained the smallest percentage of dry matter and protein. The percentage of protein in all carcasses did not deviate from its mean content in the muscle tissue of other fish species (13\% to 25\%) [21]. It is noteworthy that the protein of common carp, regardless of the production technology, contains essential amino acids in amounts much higher than in the standard protein [22]. This protein contains a higher percentage of amino acids such as phenylalanine, leucine, isoleucine, threonine, methionine, cystine, and valine, compared with beef, pork, or mutton $[21,23]$. From a nutritional point of view, the protein of 


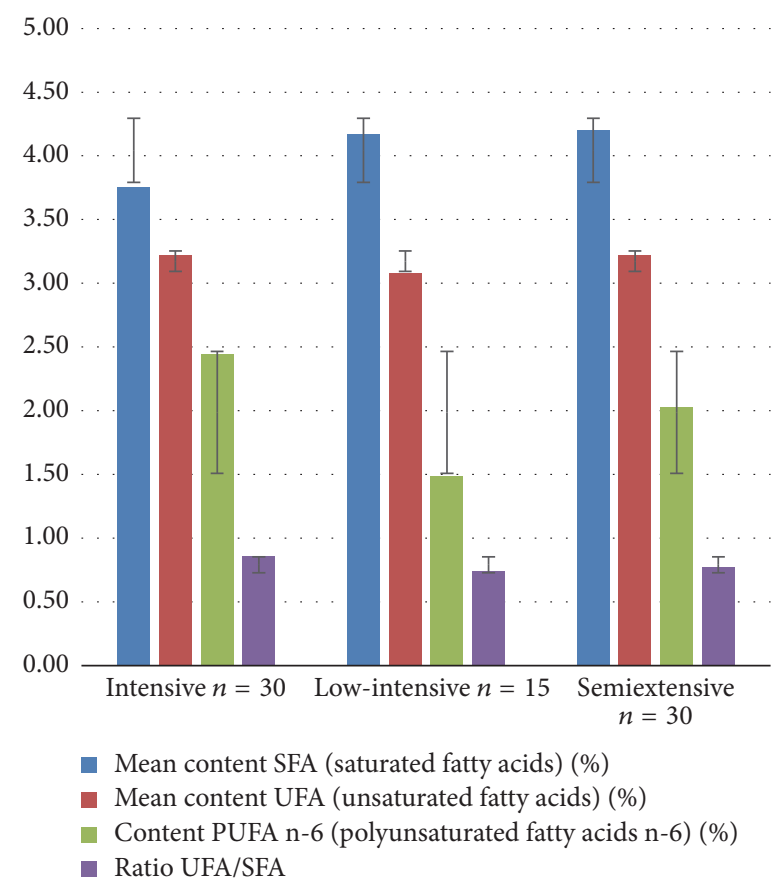

FIGURE 1: Selected parameters of fatty acid profile of carp muscle tissue under study.

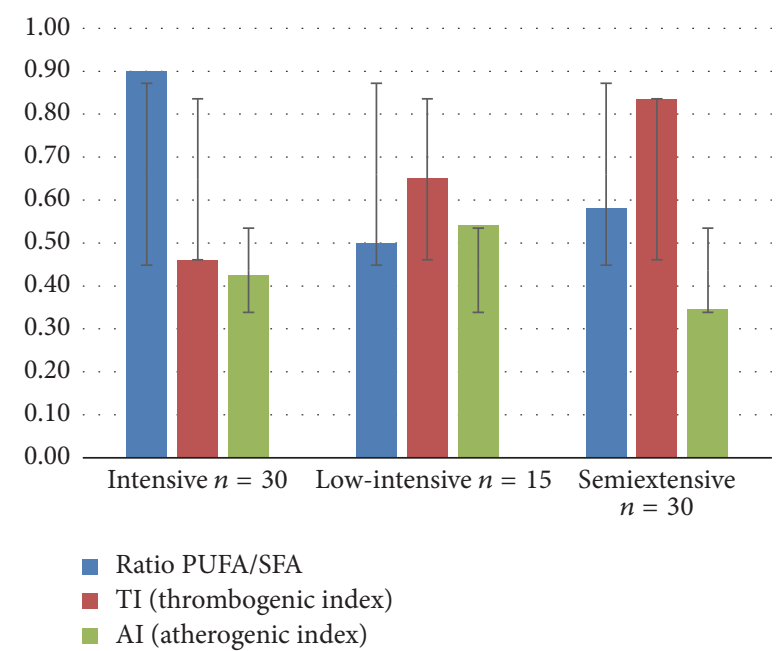

FIGURE 2: Selected parameters of fatty acid profile of carp muscle tissue under study (ctd.).

this fish species is regarded as complete. The composition of rainbow trout muscle tissue (another freshwater fish) is similar. A deficit of essential amino acids in the human diet has been shown to result in many adverse changes in the body. A sufficient supply of valine helps to maintain the right coordination of movements, the right body weight, function of dendritic cells, and a feeling of hunger. A deficit of leucine can lead to neurological disorders and a deficit of methionine impairs body immunity [24].

It has been shown in a number of studies that the type of feed given to fish affects the chemical composition of their muscle tissue. The fatty acid profile, affected by the type of feed, is very important in human nutrition. Unlike the meat of slaughter animals, fish fat is also a rich source of vitamins $A$ and D [24]. Like marine fish, freshwater fish can be a rich source of essential fatty acids; when included in the diet, they supply the body with cardioprotective, hypotensive, and antitumour substances $[11,25]$. The availability of omega-3 fatty acids for different human tissues depends on the diet and is of great importance both for their correct development and for prevention and treatment of chronic diseases [26]. Similar observations were included in the paper by Grela et al. [27], who analysed the composition of marine and freshwater fish muscle tissue. Their muscle tissue was found to contain the highest percentage of C16:0 palmitic (ca. 20\%) and C18:0 stearic acid, although the content of the latter in the samples was much lower. Similarly, the highest percentage of palmitic acid in the fatty acid profile was found in muscle tissue of other freshwater fish of South Asia, rohu (Labeo rohita) of the Cyprinidae family and Mozambique tilapia (Oreochromis mossambicus) [28], as well as muscle tissue of common carp from Lake Beyşehir in Turkey and rainbow trout (15-18\%) bred in Poland [24], which indicates that this fatty acid dominates the MUFA profile in fat of freshwater fish regardless of the climate and season [29]. Monounsaturated fatty acids reduce the level of "bad" cholesterol (LDL) and increase the level of "good" cholesterol (HDL) in blood $[30,31]$. The same results were obtained in a study of the common carp muscle tissue composition conducted by Guler et al. [29]. They also demonstrated seasonal variability of the content of total fat in fish carcasses, with the highest content observed in winter $(4.45 \%)$.

The preparation given to the fish contained $56 \%$ of protein and $11 \%$ of lipids. It is important to be able to model the lipid profile of food because fats are the main highenergy nutrient. It has been shown in numerous studies that high consumption of fat and its improper composition can stimulate the development of civilizational diseases. The fatty acid profile, especially the proportion of saturated to mono- and polyunsaturated acids, is of particular importance. Polyunsaturated essential omega- 3 and omega- 6 fatty acids are not synthesised in the human body and they must be supplied with food $[32,33]$. The group's main representative ones include $\alpha$-linolenic acid (C18:3) of the n-3 family; it is a precursor of C20:5 n-3 eicosapentaenoic (EPA) and 22:6 n-3 docosahexaenoic acid (DHA) and linoleic acid (C18:2 n-6), a precursor of C20:4 n-6 arachidonic acid (AA) [34]. Modelling of PUFA content of the muscle tissue of freshwater fish is of interest to numerous researchers. A similar experiment was conducted in the Czech Republic by Mraz and Pickova (2011) [35] who also analysed three systems of nutrition. In the first one, the fish had access to plankton; in the second one, the fish had access to plankton with the addition of cereals and rapeseed cake granules. The fatty acid profile in the white muscles of fish was then analysed. The muscles of fish which were not provided with supplements were characterised by a high content of n-3 PUFAs (in particular EPA and DHA). The supplementation with rapeseed cake granules resulted in the PUFA n-3 content being at a moderate level. The addition of cereals led to a high 
content of oleic acid and a low content of n-3 polyunsaturated fatty acids.

Similar literature reports have also pointed to freshwater fish as a valuable source of omega-3 fatty acids and emphasised their significant role in the daily diet $[36,37]$. Another method for modifying the composition of fatty acids is the application of the finishing feeding strategy. Since the composition of fish muscles is highly variable, it would be valuable if producers could produce raw material with a high and repeatable level of $n-3$ polyunsaturated fatty acid content. The difficulties primarily encountered by fish breeders who intend to enrich the feed with components providing n-3 PUFAs include the increasingly rare use of fish oil as well as a high price and low availability of algae and microorganisms. For this reason, the possibility is being considered of the application of finishing feeding developed with the following in mind: species of carnivorous fish and those with a medium fat content, such as the turbot (Psetta maxima), fatty fish such as the Atlantic salmon (Salmo salar), and lean fish such as the Atlantic cod (Gadus morhua) and the Murray cod (Maccullochella peelii peelii) [38]. Supplementation serves a significant role in nutrition. The content of n-3 HUFAs (highly unsaturated fatty acids) can be increased with the supplementation of ALA, taking advantage of the common carps' capacity for bioconversion of ALA into n-3 HUFAs [35]. An effect of feed modification on the fatty acid profile was studied by Menoyo et al. [39], who examined how an addition or total substitution of feed with linseed oil will influence the quality of muscle tissue of Atlantic salmon. It has been shown that feed can be fully substituted with linseed oil, with no effect on the productivity or sensitivity of muscles to oxidation of lipids. Linseed oil affected the metabolism of fatty acids in the liver, increasing the activity of glucose-6-phosphate dehydrogenase and accumulation of C20:4 n-6 eicosatetraenoic acid. This was accompanied by a decrease in the concentrations of C20:5 n-3 eicosapentaenoic and C22:6 n-3 docosahexaenoic acid in fish muscle tissue. According to the analysis of factors affecting the distribution of fatty acids within the muscle tissue of the common carp, carried out by Mraz and Pickova (2011) [35], a fish fillet is not uniform, and thus the distribution of fatty acids in the muscles varies. The highest lipid content was noted in the abdominal wall (approx. 30\%) and in the red muscles (16-17\%), while the lowest was in the white dorsal muscles (approx. 1-2\%). The role of genetic factors must not be omitted. It was demonstrated that the fatty acid content of the muscle tissue is hereditary; moreover, there is a positive correlation between the body size (body length and weight) and the lipid content [40]. Consideration of the effect of external factors on the quality of fish muscle tissue should also take into account the climate. Çelik et al. [41] examined the composition of muscle tissue of zander (Sander lucioperca) and showed that a higher percentage of omega3 fatty acids were present in muscle tissue of fish bred in a colder climate. Furthermore, Çağlak and Karsli [42] showed seasonal influences not only on the lipid index of the edible portion of zander, but also on higher content of aspartic acid, glutamic acid, and lysine in muscle tissue of these fish in autumn than in spring. Similar results were presented in a study conducted by Guler et al. [29], where a significantly higher omega-3 to omega- 6 acid ratio was shown during a spawning period as well as in spring and in autumn. Pleadin et al. [43] investigated the impact of seasonal changes and the location of breeding farms in the Adriatic Sea on the chemical composition of sea brass (Dicentrarchus labrax) and sea bream (Sparus aurata). The study was conducted in October 2012 and January 2013. They showed a significant influence of seasonality on moisture content and fat content in fish muscle tissue, while the location of farms did not significantly influence the indicators. The value of these relations is similar to other species of fish such as $S$. schall or T. lineatus, where PUFA/SFA ratios are 0.4 and 1.7, respectively. The lower values of the ratio of polyunsaturated to saturated fatty acids are characterised by muscle tissue of species such as L. niloticus, B. bajad, and O. niloticus [44].

There are two dietary indexes associated with the lipid profile: the atherogenic index and the thrombogenic index. Atherogenesis denotes the development of atherosclerotic changes in blood vessels, which result in the development of ischaemic heart disease. A negative lipid ratio in blood speeds up atherogenesis. Thrombogenic components denote particles which facilitate the formation of blood clots. Edible fats are classified into two types: atherogenic (i.e., those that favour the development of atherosclerotic changes) and antiatherogenic (which have an antiatherosclerotic effect). Most animal fats have an atherogenic effect due to the high content of saturated fatty acids and cholesterol. The other group includes mainly vegetable oils [45]. This means that the fat has much higher antiatherosclerotic and cardioprotective properties than milk fat and emphasises its pro-health value. The thrombogenic index, which for milk ranges from 3.75 to 4.71 , is another parameter which indicates the beneficial properties of common carp fat [46]. The nutritional value of the common carps tested, given indicators such as the thrombogenicity index and the atherogenic index, was very favourable, as was the case with commercially important species of marine fish such as bream (Sparus aurata), sea bass (Dicentrarchus labrax), dentex (Dentex dentex), and turbot (Scophthalmus maximus) [47].

The findings suggest that the muscle tissue of common carp and other freshwater fish can be a valuable replacement for marine fish in the diet. It is a rich source of PUFA in desired proportions. Moreover, there is a distinct, beneficial effect of intensive technology of fish breeding on selected parameters of lipid profile, the amount of components with the cardioprotective action, total amount of fat, and the associated content of fat-soluble vitamins. The differences in results for samples obtained from various types of farms arise from the type of feed given to the animals. The feed given in the semiextensive technology was a cereal mixture: wheat, barley, and rye in the ratio of $3: 1: 1$, or only fishing bait; in the low-intensive technology it was a cereal mixture-wheat, barley, and rye in the ratio of $2: 1: 1$ - or a cereal mixture-maize + wheat and barley in the ratio of $1: 3$. The fish were given industrial feeds in the intensive production technology; these were made of the following ingredients: yeast, wheat gluten, fish meal, krill meal, fish oil, wheat, vitamins, minerals, and amino acids. 
Their composition was much more diverse; it contained both complete animal protein and plant protein. An addition of fish oil in the right proportions, especially saturated fatty acids, allows for modification of the composition of fatty acids in the bodies of fed animals. Yeasts are used in animal feeding as a source of vitamin B, some bioelements, enzymes, and digestible protein. They have a beneficial effect on intestinal flora and stimulate the growth and development of young animals and their health and productivity [48].

\section{Conclusions}

(1) The type of production technology, especially intensive breeding technique, has a significant effect on dry weight and total fat in the common carp muscle tissue under study.

(2) The type of feed used in intensive, low-intensive, and semiextensive common carp breeding has a highly significant effect on the fatty acid profile. Regardless of the technology of common carp breeding, fish fat has a beneficial proportion of unsaturated (UFA) to saturated (SFA) fatty acids and is a rich source of polyunsaturated fatty acids (PUFAs).

(3) Low values of atherogenic index (AI) and thrombogenic index (TI) of common carp fat indicate its antiatherosclerotic and cardioprotective properties, which are much stronger than in milk fat. This confirms the pro-health properties of fat in common carp muscle tissue.

(4) Owing to its nutritional and pro-health value, muscle tissue of common carp, especially from intensive breeding, can be a complete substitute for marine fish in the human diet.

\section{Conflicts of Interest}

The authors declare that there are no conflicts of interest regarding the publication of this paper.

\section{Acknowledgments}

The authors would like to express their gratitude to Dr. Janusz Zakrzewski for help in conducting the experiment and obtaining the results necessary to write this publication.

\section{References}

[1] P. Skalecki, M. Florek, A. Litwinczuk et al., "Wartosc uzytkowa i sklad chemiczny miesa karpi (Cyprinus common carpio L.) i pstragów teczowych (Oncorhynchus mykiss Walb.) pozyskanych $\mathrm{z}$ gospodarstw rybackich regionu lubelskiego," Roczniki Naukowe Towarzystwa Zootechnicznego, vol. 9, no. 2, pp. 57-62, 2013.

[2] K. Achremowicz and K. Szary-Sworst, "Wielonienasycone kwasy tluszczowe czynnikiem poprawy stanu zdrowia czlowieka," Zywnosc. Nauka. Technologia. Jakosc, vol. 3.44, pp. 23-35, 2005.

[3] K. Bieniarz, F. Borowiec, and Z. Okoniewski, "Zawartosc tluszczu, kwas $\leq \mathrm{w}$ tluszczowych i cholesterolu w miesniach karpi (Cyprinus common carpio L.) chowanych w $\mathrm{r} \leq \mathrm{znych}$ warunkach pokarmowych. Roczniki Naukowe Zootechniki," Suplement, vol. 12, pp. 129-135, 2001.

[4] W. Steffens, "Aquaculture produces wholesome food: cultured fish as a valuable source of n-3 fatty acids," Aquaculture International, vol. 24, no. 3, pp. 787-802, 2016.
[5] J. Ciborska, "Lipidy w żywności, żywieniu i zdrowiu człowieka Cz. II. Aspekty żywieniowe i zdrowotne," PRZEMYSE SPOŻYWCZY, vol. 1, no. 9, pp. 46-51, 2017.

[6] K. A. Skibniewska and J. Zakrzewski, “Technologia produkcji rybackiej a jakosc karpia. Wplyw rodzaju technologii produkcji rybackiej i jakosci srodowiska wodnego na wybrane wskazniki hodowlane i patomorfologiczne karpia konsumpcyjnego (Cyprinus common carpio L.)," Olsztyn, Wydanie w ramach projektu Sektorowego Programu Operacyjnego , ,Rybołówstwo $i$ Przetwórstwo Ryb 2004-2006” wspólfinansowanego przez Unię Europejską, pp. 65-72, 2008 (Portuguese).

[7] A. Sánchez-Villegas, L. Verberne, J. De Irala et al., "Dietary Fat Intake and the Risk of Depression: The SUN Project," PLoS ONE, vol. 6, no. 1, p. e16268, 2011.

[8] A. P. DeFilippis, M. J. Blaha, and T. A. Jacobson, "Omega-3 fatty acids for cardiovascular disease prevention," Current Treatment Options in Cardiovascular Medicine, vol. 12, no. 4, pp. 365-380, 2010.

[9] J. Tkaczewska and W. Migdał, "Porównanie wydajności rzeźnej, zawartości podstawowych składników odżywczych oraz poziomu metali ciężkich $\mathrm{w}$ mięśniach karpi (Cyprinus common carpio L.) pochodzacych z róznych rejonów Polski," ŻYWNOŚĆ. Nauka. Technologia. Jakość, vol. 6, no. 85, pp. 180-189, 2012.

[10] R. Puchala, M. Pilarczyk, and R. Puchała, "Wpływ żywienia na skład chemiczny mięsa karpia," Inżynieria rolnicza, vol. 5, no. 93, pp. 363-368, 2007.

[11] W. Steffens and M. Wirth, "Influence of nutrition on the lipid quality of pond fish: Common carp (Cyprinus carpio) and tench (Tinca tinca)," Aquaculture International, vol. 15, no. 3-4, pp. 313-319, 2007.

[12] V. Adamkova, J. Mraz, P. Kacer, and P. Suchanek, “The consumption of common carp meat and plasma lipids in secondary prevention in the heart ischemic disease patients," Neuroendocrinol. Lett, vol. Lett. 32, no. Suppl. 2, pp. 101-104, 2011.

[13] K. J. Filipiak and G. Opolski, Epidemiologiczne aspekty zaburzen lipidowych oraz terapii tych zaburzen $w$ Polsce. W Zaburzenia lipidowe, 51-64. Poznan: Termedia Wydawnictwa Medyczne, 5164. Poznań, Termedia Wydawnictwa Medyczne, 2010.

[14] AOAC, Official Methods of Analysis, Association of Official Analytical Chemists, Washington, DC, USA, 18th edition, 2005.

[15] AOAC, Official Methods of Analysis, vol. Gaithersburg, MD, USA., Gaithersburg, MD, USA., 17th ed edition, 2000.

[16] J. Folch, M. Lees, and G. H. Sloane Stanley, "A simple method for the isolation and purification of total lipides from animal tissues," The Journal of Biological Chemistry, vol. 226, no. 1, pp. 497-509, 1957.

[17] AOAC, Official Methods of Analysis, , method 996.06; Fat (Total, Saturated, Unsaturated, and Monounsaturated), VA, USA, 17th edition, 2002.

[18] Z. Zegarska, J. Jaworski, Z. Borejszo, and Z. Żegarska, "Ocena zmodyfikowanej metody Peiskera otrzymywania estrow metylowych kwasow tluszczowych," Acta Academiae Agriculturae ac Technicae Olstenensis, Technologia Alimentorum, 1991.

[19] J. Gawęcki, “Żywienie człowieka. Podstawy nauki o żywieniu. Wydawnictwo Naukowe PWN," 2016.

[20] T. L. V. Ulbricht and D. A. T. Southgate, "Coronary heart disease: seven dietary factors," The Lancet, vol. 338, no. 8773, pp. 985992, 1991.

[21] V. V. Vladau, I. Bud, and S. Reka, "Nutritive value of fish meat comparative to some animals meat," in Bulletin of the University 
of Agricultural Sciences \& Veterinary Medicine Cluj-Napoca, vol. 65, pp. 301-305, Animal Science \& Biotechnologies, 2008.

[22] WHO/FAO/UNU, "Protein and amino acid requirements in human nutrition," Report of joint WHO/FAO/ UNU expert consultation, WHO, Geneva, Switzerland, 2002, WHO Technical Report, Series 935.

[23] K. A. Skibniewska, J. Zakrzewski, J. Kłobukowski et al., "Nutritional value of the protein of consumer carp cyprinus carpio L.," Czech Journal of Food Sciences, vol. 31, no. 4, pp. 313-317, 2013.

[24] J. Szarek, K. A. Skibniewska, J. Zakrzewski, and J. Guziur, The quality of rainbow trout (Oncorhynchus mykiss Walbaum 1972) from technologies applied in Poland. Testing the trout production technologies applied in Poland in the light of the Commission Regulation (WE) 710/2009, ElSet, Olsztyn, Poland, 2013.

[25] A. Philibert, C. Vanier, N. Abdelouahab, H. M. Chan, and D. Mergler, "Fish intake and serum fatty acid profiles from freshwater fish," American Journal of Clinical Nutrition, vol. 84, no. 6, pp. 1299-1307, 2006.

[26] R. Xu, "Important bioactive properties of omega-3 fatty acids," Italian Journal of Food Science, vol. 27, no. 2, pp. 129-135, 2015.

[27] E. R. Grela, R. K. Pisarski, E. Kowalczuk-Vasilev, and A. Rudnicka, "Zawartosc skladnikow odzywczych, mineralnych i profil kwasów tluszczowych w miesie wybranych gatunkow ryb w zależnosci od terminu odłowu," Żywność Nauka Technologia Jakość, vol. 17, no. 4, pp. 63-72, 2010.

[28] F. Jabeen and A. S. Chaudhry, "Chemical compositions and fatty acid profiles of three freshwater fish species," Food Chemistry, vol. 125, no. 3, pp. 991-996, 2011.

[29] G. O. Guler, B. Kiztanir, A. Aktumsek, O. B. Citil, and H. Ozparlak, "Determination of the seasonal changes on total fatty acid composition and $\omega 3 / \omega 6$ ratios of carp (Cyprinus carpio L.) muscle lipids in Beysehir Lake (Turkey)," Food Chemistry, vol. 108, no. 2, pp. 689-694, 2008.

[30] R. P. Mensink, P. L. Zock, A. D. M. Kester, and M. B. Katan, "Effects of dietary fatty acids and carbohydrates on the ratio of serum total to HDL cholesterol and on serum lipids and apolipoproteins: a meta-analysis of 60 controlled trials," American Journal of Clinical Nutrition, vol. 77, no. 5, pp. 1146-1155, 2003.

[31] C. M. Williams, "Dietary fatty acids and human health," Annales de Zootechnie, vol. 49, no. 3, pp. 165-180, 2000.

[32] R. J. Nicolosi, "Dietary fat saturation effects on low-densitylipoprotein concentrations and metabolism in various animal models," American Journal of Clinical Nutrition, vol. 65, no. 5, 1997.

[33] S. Yu, J. Derr, T. D. Etherton, and P. M. Kris-Etherton, "Plasma cholesterol-predictive equations demonstrate that stearic acid is neutral and monounsaturated fatty acids are hypocholesterolemic," American Journal of Clinical Nutrition, vol. 61, no. 5, pp. 1129-1139, 1995.

[34] D. Ljubojević, V. Radosavljević, N. Puvača et al., "Interactive effects of dietary protein level and oil source on proximate composition and fatty acid composition in common carp (Cyprinus carpio L.)," Journal of Food Composition and Analysis, vol. 37, pp. 44-50, 2015.

[35] J. Mraz and J. Pickova, "Factors influencing fatty acid composition of common common carp (Cyprinus common carpio) muscle," Neuroendocrinol, vol. 32, no. 2, pp. 3-8, 2011.

[36] S. Bulut, "Fatty acid composition and $\omega 6 / \omega 3$ ratio of the pike (Esox lucius) muscle living in Eber Lake, Turkey," Scientific Research and Essays, vol. 5, no. 23, pp. 3776-3780, 2010.
[37] Steffens, Werner, and M. Wirth, "Freshwater fish-an important source of n-3 polyunsaturated fatty acids: a review," Archiwum Rybactwa Polskiego, vol. 13, no. 1, pp. 5-16, 2005.

[38] J. Mráz, T. Zájic, and J. Pickova, "Culture of common carp (Cyprinus carpio) with defined flesh quality for prevention of cardiovascular diseases using finishing feeding strategy," Neuroendocrinology Letters, vol. 33, no. 2, pp. 60-67, 2012.

[39] D. Menoyo, C. J. López-Bote, A. Obach, and J. M. Bautista, "Effect of dietary fish oil substitution with linseed oil on the performance, tissue fatty acid profile, metabolism, and oxidative stability of Atlantic salmon," Journal of Animal Science, vol. 83, no. 12, pp. 2853-2862, 2005.

[40] M. Kocour, S. Mauger, M. Rodina, D. Gela, O. Linhart, and M. Vandeputte, "Heritability estimates for processing and quality traits in common carp (Cyprinus carpio L.) using a molecular pedigree," Aquaculture, vol. 270, no. 1-4, pp. 43-50, 2007.

[41] M. Çelik, A. Diler, and A. Küçükgülmez, "A comparison of the proximate compositions and fatty acid profiles of zander (Sander lucioperca) from two different regions and climatic conditions," Food Chemistry, vol. 92, no. 4, pp. 637-641, 2005.

[42] E. Çağlak and B. Karsli, "Seasonal Variation Of Fatty Acid And Amino Acid Compositions In The Muscle Tissue Of Zander (Sander Lucioperca Linnaeus, 1758) And The Evaluation Of Important Indexes Related To Human Health," Italian Journal of Food Science, vol. 29, no. 2, pp. 266-275, 2016, ISSN 1120-1770.

[43] J. Pleadin, M. Petrovic, G. Krešic, S. Zrncic, D. Oraic, and N. Džafic, "Influence of season and farming location on the quality parameters of sea bass (dicentrarchus labrax) and sea bream (sparus aurata)," Italian Journal of Food Science, vol. 27, no. 2, pp. 23-31, 2015.

[44] E. Mohamed and G. N. Al-Sabahi, "Fatty acids content and profile of common commercial Nile fishes in Sudan," International Journal of Fisheries and Aquaculture, vol. 3, no. 6, pp. 99-104, 2011.

[45] G. Cichosz and H. Czeczot, "Zywieniowy fenomen mleka," Zaklad Poligraficzny Uniwersytetu Warminsko- Mazurskiego $w$ Olsztynie, 2013.

[46] W. Sobotka, M. Stanek, and E. Fiedorowicz, "Fiedorowicz, E. 2015. Prozdrowotne właściwości tłuszczu mlekowego w zależności od rasy krów," Probl. Hig. Epidemiol, vol. 96, no. 4, pp. 808-811, 2015.

[47] J. Pleadin, T. Lesic, R. Baric et al., "Nutritional quality of different fish species farmed in the Adriatic Sea," Italian Journal of Food Science, vol. 29, no. 3, pp. 1120-1770, may 2017.

[48] R. Klebaniuk, E. Kowalczuk-Vasilev, and M. Olcha, "Drożdże i ich metabolity w efektywnym żywieniu bydła. Bydło," Bydło, vol. 4, pp. 14-18, 2013. 


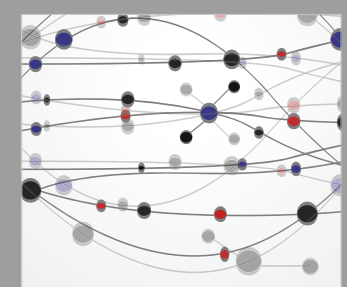

The Scientific World Journal
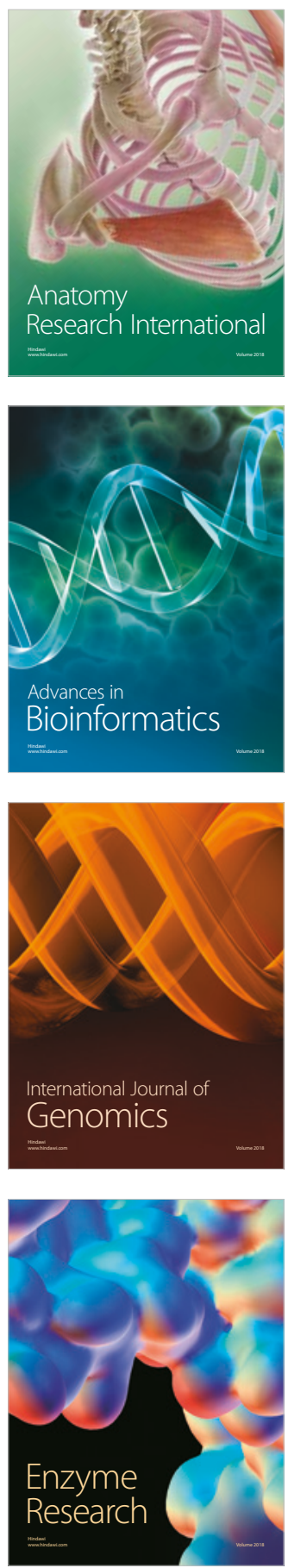
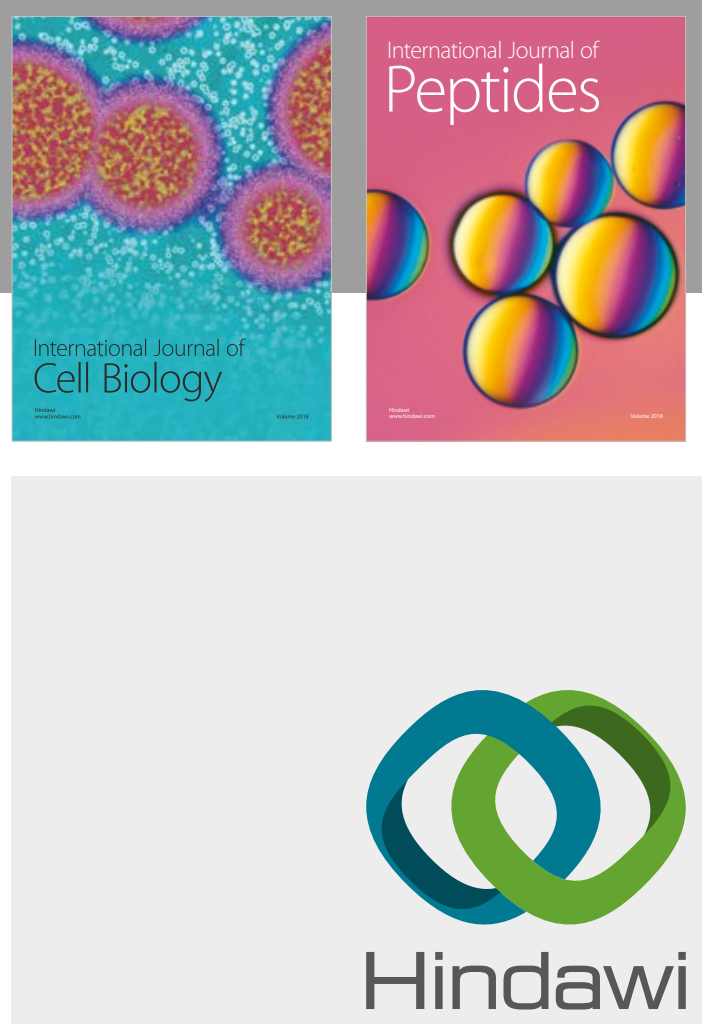

Submit your manuscripts at

www.hindawi.com
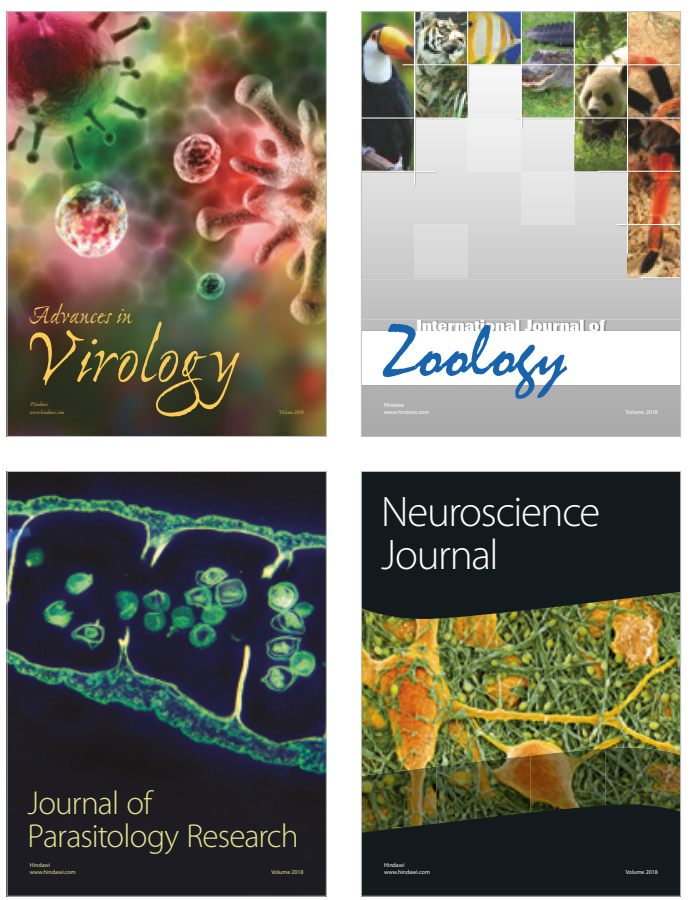
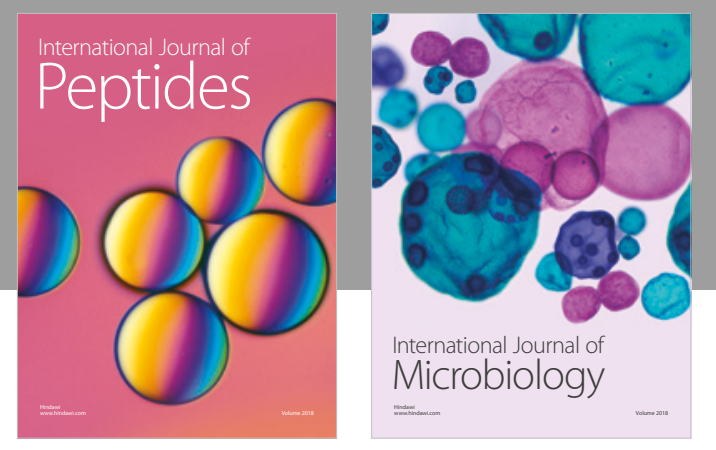

nternational Journal of Microbiology
Journal of
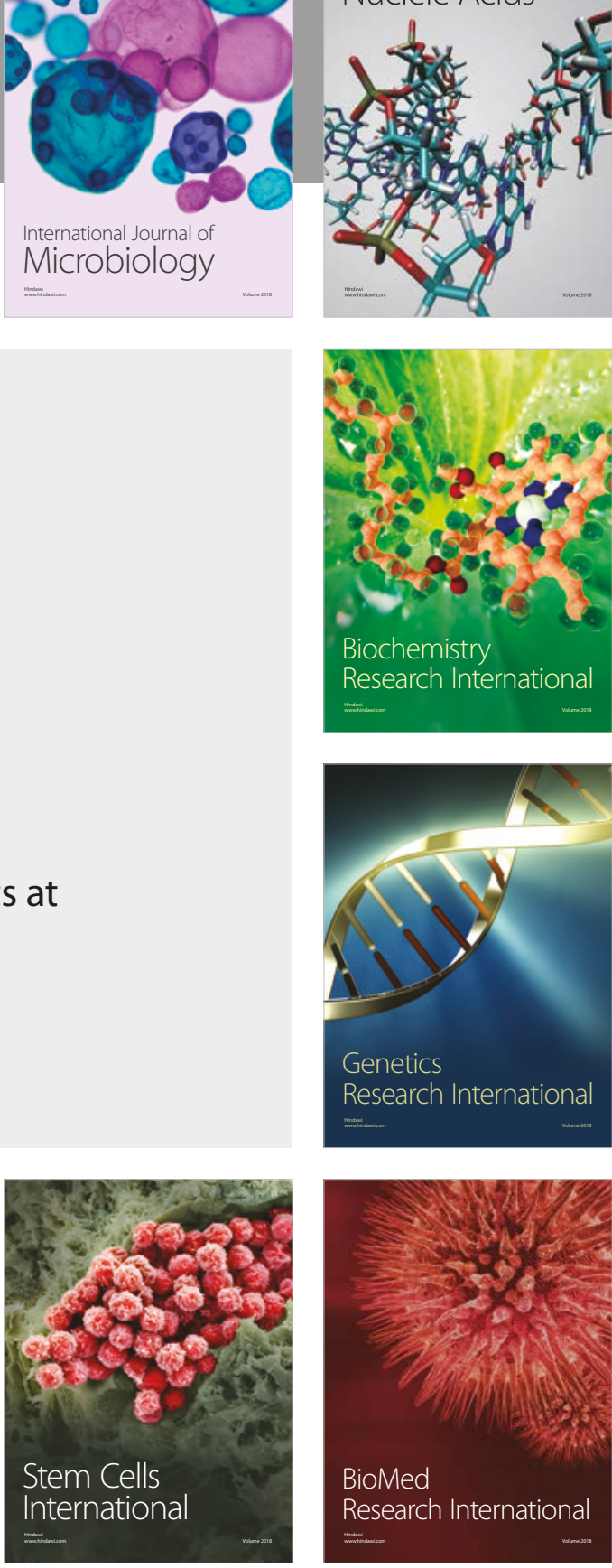
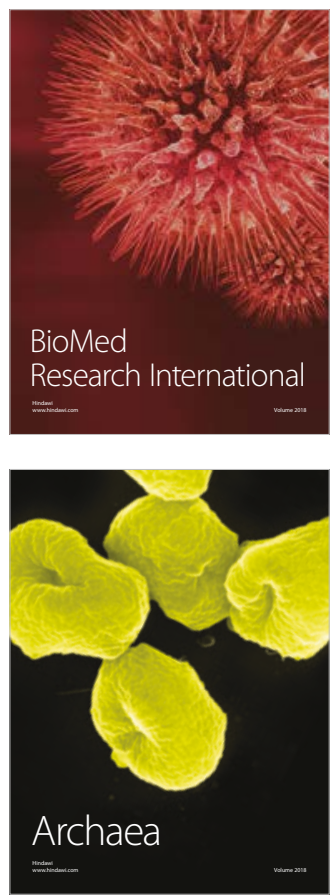